\title{
GON-4-Like Protein
}

National Cancer Institute

\section{Source}

National Cancer Institute. GON-4-Like Protein. NCI Thesaurus. Code C132122.

GON-4-like protein (2241 aa, $249 \mathrm{kDa}$ ) is encoded by the human GON4L gene. This protein plays a role in the repression of gene transcription. 